\title{
Implementation of Zakat Mal Management Based on Law Number 23 Year 2011 in Institution Amil Zakat Muhammadiyah, Medan City
}

\author{
Nispul Khoiri' ${ }^{1}$, Ramadhan Syahmedi $\operatorname{Srg}^{2}$, Izhar ${ }^{3}$ \\ 1,2,3 Universitas Islam Negeri Sumatera Utara, Indonesia \\ izharkisaran15@gmail.com
}

\begin{abstract}
This study aims to find the problems and strategies carried out by the Lazis Muhammadiyah management in Medan are divided into two, namely internal and external. And what is being done is an effort to raise awareness together to channel zakat al-mal to Lazis Muhammadiyah so that it is managed properly and transparently and evenly so that it directly touches the community so that the objectives of the zakat law are realized. Management of zakat based on Law Number 23 of 2011 is zakat management states that zakat management aims to increase the effectiveness and efficiency of services in managing zakat; and increase the benefits of zakat to create social welfare and poverty alleviation. Efforts to realize the function and role of zakat in the welfare of society, the zakat management law issued by the government is in principle to facilitate, motivate and confirm the management of zakat issued by the Amil Zakat Agency or the Amil Zakat Institute.
\end{abstract}

Keywords

implementation of zakat mal management; Law, Amil Zakat Muhammadiyah accounting students, and accountants

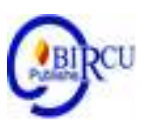

\section{Introduction}

Indonesia is a country with a majority Muslim population, even though Indonesia is the only country with a majority Muslim population, even though the Republic of Indonesia is not an Islamic country. But in line with that, the participation of the Indonesian Muslim community in this matter through zakat has a great opportunity to realize the goals of the Republic of Indonesia. As the ideals set forth in the preamble to the Constitution of the Republic of Indonesia which contains "advancing public welfare and educating the nation's life.

On this basis, it is hoped that zakat can become a system that is structurally capable of overcoming the problem of poverty and encouraging the development of the people's economy and the nation's economy. Even the ethical value in the aspect of zakat should be explored and developed, such as poverty alleviation and economic empowerment. The assessment of zakat values will have an impact on thinking about how to manage economic resources more rationally and efficiently, so that the social and economic community aspirated by Islam and the ideals of the Indonesian state can be achieved optimally.

In an effort to alleviate poverty, President Susilo Bambang Yudhoyono hopes that policy synergy between the central government and regional governments will be carried out by involving the private sector and the wider community.In this case, what the researcher meant about the existence of the Amil Zakat Muhammadiyyah Institute (LAZMU).

The participation of Indonesian Muslims in poverty alleviation is considered very strategic because apart from sociological arguments it is also a religious order. In the development of Islam in Indonesia, one of the influential institutions is zakat. Zakat is in 
Islamic doctrine, which is the fourth pillar of Islam, and is built before shahada, prayer and fasting. Therefore, it is highly suspected that the im

plementation of zakat among Muslims has been carried out in this archipelago along with their existence and is seen as part of the implementation of Islam. In connection with the implementation of the Islamic religion on zakat in the Republic of Indonesia, Uswatun Hasanah, stated that Muslims who are the majority of the population in Indonesia have long been implementing zakat institutions. It is further stated that, the implementation of zakat in addition to religious orders is also an effort to realize social justice in the economic field.

Therefore, the management of zakat is deemed necessary to be legally enacted in order to realize the vision and mission of zakat and the ideals of the country. The Indonesian government as the executive has passed the Law on the management of zakat, namely in 1999. Which this Law will become a positive law, which will later accommodate Muslims regarding awareness of their rights and obligations towards their religion and their social relationship with zakat.

Table 1. Data on ZIS Recipients for Jnauari-December 2019

\begin{tabular}{|c|r|r|r|r|r|}
\hline Month & \multicolumn{1}{|c|}{ Zakat } & \multicolumn{1}{c|}{ Infak } & \multicolumn{1}{c|}{ Mukayyat } & \multicolumn{1}{c|}{ Zakat Fitrah } & \multicolumn{1}{c|}{ Total } \\
\hline January & Rp.5.466.875 & Rp.38.909.889 & Rp.2.715.011 & & Rp.47.091.775 \\
\hline February & Rp.2.790.000 & Rp.30.733.900 & & & Rp.33.523.900 \\
\hline March & Rp.2.250.000 & Rp.36.528.400 & Rp.3.860.000 & & Rp.42.638.400 \\
\hline April & Rp.1.250.000 & Rp.63.371.600 & Rp.1.790.000 & & Rp.66.411.600 \\
\hline May & Rp.16.400.000 & Rp.89.417.300 & Rp.5.030.000 & & Rp.110.847.300 \\
\hline June & Rp.38.570.000 & Rp.175.305.400 & Rp.150.000 & Rp.488.000 & Rp.214.513.400 \\
\hline July & Rp.1.463.625 & Rp.55.929.900 & Rp.5.899.000 & & Rp.63.292.525 \\
\hline August & Rp.1.825.000 & Rp.46.544.600 & Rp.1.000.000 & & Rp.49.369.600 \\
\hline September & Rp.13.375.000 & Rp.55.197.400 & Rp.3.489.500 & & Rp.72.061.900 \\
\hline October & Rp.700.000 & Rp.49.475.900 & Rp.36.542.700 & & Rp.86.718.600 \\
\hline November & Rp.1.685.000 & Rp.40.396.000 & Rp.300.000 & & Rp.42.381.000 \\
\hline December & Rp.1.145.000 & Rp.47.329.100 & Rp.7.835.300 & & Rp.56.309.400 \\
\hline Total & Rp.86.920.500 & Rp.729.139.389 & Rp.68.611.511 & Rp.488.000 & Rp.884.671.400 \\
\hline
\end{tabular}

Data: LAZ Muhammadiyah Medan City Office, Tuesday, March 11, 2020

\section{Review of Literature}

\subsection{Definition of Zakat}

In terms of language, the word zakat is the root word (mashdar) from the word zakka which means blessing, clean and developing. According to Ibn Manzur Alam Lisan al'Arab, the word zakat according to language means growth, blessing and praise, where all these words are used in the Koran and Hadith. According to Wahidi Dam, the word zakka means increasing and growing so that it can be said that the plant is zakka, which is growing. When a plant grows, the word zakka here dares to be clean and if someone is given the characteristic of zakat, it means good, then that person has more good qualities.

Zakat is called a blessing, because by paying zakat the wealth will be doubled or not reduced so that it will make the property grow like a seed that grows seven ears on each one hundred seeds, because of the gifts and blessings given by Allah SWT. to a muzakkzi, as the word of Allah swt. in surah al-baqarah verse 261 ..

Meaning: "The parable (income incurred by) of those who spend their wealth in the way of Allah is similar to a seed that grows seven ears, on each one hundred seeds. Allah multiplies (rewards) for whom He wills. and Allah is Vast (His gift), All-knowing ". (QS. Al-Baqarah verse 261). 


\subsection{Legal Basis for Zakat Mal}

The first zakat is required in the month of Shawwal in the second year of Hijriyah after the month of Ramadan it is obligatory to zakat fitrah, then zakat mal and wealth is required. Zakat hukmnnya fardhu 'ain for every Muslim whose terms and conditions have been fulfilled. The command to issue zakat in the Koran often uses the terms alms, donations and zakat which in everyday terms are assets for which rights must be issued.

As for the basic sources of zakat law, among others, in the letter At-taubah verse 103.

Meaning: "Take Zakat from their property, with that zakat you clean and purify them and pray for them. In fact, your prayer (becomes) peace of mind for them and Allah is AllHearing All-Knowing." (Surah at-Taubah, verse 103).

According to Ibn 'Umar, what is meant by the above rights are the parts that must be removed from our assets for the groups who need them, "

Meaning: "Pay zakat on your wealth." (HR. Turmuzi)

As for the assets at the time of the Prophet Muhammad that must be issued zakat, which have the size of the nisab and haul, among others:

\section{a. Gold and Silver}

Zakat Gold and silver are one of the zakat males required by Allah SWT, as Allah SWT says.

Meaning: "O you who believe, Verily most of the pious Jews and Christian monks really eat people's property with vanity and they hinder (humans) from the Way of Allah and those who keep gold and silver and do not spend them in the way of Allah, So tell them, (that they will get) a painful punishment." (Surah At-Taubah verse 34).

\section{Gold Nishab and Zakat Levels}

Ibnu Munzir said, "the experts have ijma '(agree that if there is 20 mitsqal of gold and the price is 200 dirhams, it is obligatory for zakat. Strictly speaking, the nishab of gold which does not reach the gold standard is 20 mitsqal. Most jurists say," the gold nisab is 20 mitsqal with no. see the price. "That was the opinion of Abu Hanifah, Malik, Asy-shafi and Ahmad.

Ibn Hazm reported from ibn Hazim's finger from Ali that the Prophet SAW said.

Meaning: "You do not have anything for the value of the gold, 20 dinars. If you have 20 dinars and you have up to a year, then the zakat is half a dinar, and the one that is more according to the calculation."

From the above hadith, the scholars stipulate that the nisab of gold is 20 dinars of pure gold or the equivalent of 85 grams of $24 \mathrm{~K}$ gold. Then the zakat is one forty or $2,5 \%$.

\section{Silver Nisab and Zakat}

The scholars agreed in determining the nisab of silver based on the hadith narrated by Bukhari from Abu Sa'id from the Prophet;

Meaning: "There is no zakat for silver less than 5 auqiyah".

1 auqiyah $=40$ dirhams, 5 auqiyah $=5 \mathrm{X} 40$ dirhams is equal to 200 dirhams and the zakat is $2.5 \%$ which is 5 dirhams. 


\section{b. Zakat on Plants and Fruits (Agricultural Products)}

Zakat from crops is zakat collected from agricultural products, fruits and plants. Agricultural zakat that is collected is only the result, while zakat on trade, gold and silver and livestock are calculated by including capital and yield. This is where the difference between zakat on agricultural products and zakat on trade, gold, silver and livestock. The legal basis for zakat on crops (agriculture). As stated in the Koran in the letter al-An'am: 141.

Meaning: "And it is He who makes gardens that are upright and not uplifting, date palms, plants of various fruits, olives and pomegranates that are similar (in shape and color) and not the same (taste), eat of their fruit (which all kinds of things) if he bears fruit, and fulfill his rights on the day of reaping the results (by giving to the poor), and don't overdo it. Indeed, Allah does not like people who are extravagant." (Surah al-An'am: 141).

\section{c. Cattle}

Regarding livestock, the type has been determined by the Prophet. And after his death by his friends, namely livestock such as camels, cows (ox), and goats. Because the traditions only explain the obligation of zakat on the animals mentioned above.

In Yusuf Qardawi's term, what is meant by livestock is an animal that is useful for humans. By the Arabs it is called "al-an'am", namely: camels, cows including buffaloes, goats and sheep, as mentioned in the Koran as livestock used for human interests, for example, their energy to lift weights, ridden as vehicles. and the milk is taken, the meat is to be eaten and the skins are taken. Because it is appropriate that Allah asks the owner to be grateful for the blessings that He has bestowed on them.

\section{Camel Zakat}

There is no zakat on camels less than five heads, male or female. For this the authors created the following table.

Table 2. Nisab and Camel Zakat Levels

\begin{tabular}{|l|l|}
\hline Nisab Camel & \multicolumn{1}{|c|}{ A lot of zakat must be paid } \\
\hline From - to & \\
$5-9$ & A goat \\
$10-14$ & 2 goats \\
$15-19$ & 3 goats \\
$20-24$ & 4 goats \\
$25-35$ & A female camel calf (over 1 year old) \\
$36-45$ & A female camel calf (over 2 years old) \\
$46-60$ & A female camel calf (over 3 years old) \\
$61-75$ & A female camel calf (over 4 years old) \\
$76-90$ & 2 female camel chicks (over 2 years old) \\
$91-120$ & 2 female camel chicks (over 3 years old) \\
\hline
\end{tabular}

\section{Zakat on Cows and Buffalo}

Buffaloes are classified into cows according to ijma ', as quoted by Ibn Mundzir, the two types of livestock can be combined. Zakat cows and buffaloes are obligatory based on hadith and consent. However, the scholars differed on the issue of the limits of cows and buffaloes which are obliged to do zakat. Some scholars argue that there is no zakat for ox less than 50 heads. If there are 50 cows, the zakat is one ox and if there are 100 cows, the zakat is two cows. Some of the other scholars have argued, among others, the opinion of Imam Malik, Asy-Shafi'i, and Ahmad that there is no zakat on cattle until they number 30 
heads. For more details about nisab and zakat levels for cows and buffaloes, please see the following table:

Table 3. Nisab and Zakat Levels for Cows and Buffalo

\begin{tabular}{|l|c|l|}
\hline No. & Nisab & \multicolumn{1}{c|}{ Level of Zakat } \\
\hline 1 & $30-39$ cows & 1 tabi' male / female cow is 1 year old entering the 2nd year \\
\hline 2 & $40-59$ cows & 1 female musinnah cow is destroyed at 2 years old into its 3rd year \\
\hline 3 & $60-69$ cows & 2 tabi' cows aged 1 year enter their second year \\
\hline 4 & $70-79$ cows & $\begin{array}{l}\text { 1 head of dead cow enters its 3rd year and 1 tabi' cow is in its 2nd } \\
\text { year }\end{array}$ \\
\hline 5 & $80-89$ cows & $\begin{array}{l}\text { 2 The tail of the musinnah cows is destroyed when it reaches its 3rd } \\
\text { year }\end{array}$ \\
\hline
\end{tabular}

Description: Issued every year, (source from the hadith of Muaz bin Jabal)

\section{Zakat Goats and Sheep}

Goats and sheep must be zakati when they reach their nisab, this is based on hadith and consent. Zakat in this type starts with the number of 40 goats and sheep. There is no obligation if it is less than this amount. More details can be seen in the following table:

Table 4. Nisab and Zakat Levels for Goats and Sheep

\begin{tabular}{|c|c|c|c|c|}
\hline No. & Nisab & Level of zakat & Time & \\
\hline 1 & $40-120$ goats & 1 goat aged 2 years & Every year & Every visit \\
\hline 2 & $121-200$ goats & 2 goats aged 2 years & Every year & bah 100 za \\
\hline 3 & $201-300$ goats & 3 goats aged 2 years & Every year & plus 1 goat \\
\hline
\end{tabular}

According to the author's opinion, the current modern era in the field of animal husbandry has also progressed, therefore zakat on livestock is not limited to those mentioned, but all livestock, the important thing is that the results have met one nisab. For example, a large number of broiler chicken breeders can exceed the results of goat or cattle or camel breeders who are subject to compulsory zakat because they reach their nisab. So for broiler chicken breeders with an income that reaches the nisab, they should also pay their zakat.

\section{d. Trade Assets/Commercial Assets}

Trade assets are goods that are prepared for trading, such as animals, clothing, jewelry, and so on. The basis for the opinion that the mandatory zakat trade objects are as follows:

This means: "O you who believe, spend (in the way of Allah) a portion of the results of your efforts are good and part of what We put out of the earth for you. and do not choose bad things and then spend from them. Though you do not want to take them yourself but by drawing your eyes to them. and know, that Allah is Rich, Praiseworthy." (Surah Al-Baqarah: 267).

\section{e. Mining Goods}

In interpreting mining goods, the jurists differed in opinion according to Hanafiyah, what is meant by mining goods is an ancient relic, while according to the majority of scholars the mining goods that must be zoned for zakat are gold and silver. Regarding this, it is stated in the word of Allah, surah al baqarah verse: 267.

This means: "O you who believe, spend (in the way of Allah) a portion of the results of your efforts are good and part of what we put out of the earth for you. And do not 
choose the bad things for your living, but you yourself are squinting at them. And know, that Allah is rich, the most praiseworthy." (Surah Al-Baqarah 267).

\section{f. Investment in Buildings, Factories, Vehicles, Equipment and Others}

The argument that commands zakat from investment returns is letter A-Baqarah 267. This means: "O you who believe, spend (in the way of Allah) a portion of the results of your efforts are good and part of what We put out of the earth for you. and do not choose bad things and then spend from them. Though you do not want to take them yourself but by drawing your eyes to them. and know that Allah is rich and praiseworthy." (Surah ABaqarah 267).

\section{g. Search and Profession Zakat}

The income that stands out the most In this millennial era, this is what is obtained from new jobs and professions such as doctors, architects, lawyers, programmers, and a myriad of other forms of profession. Some of the salaf scholars argue that the income assets are obliged to be paid for zakat as well as contemporary scholars. Therefore zakat seeking and profession can be taken even though at the time of the Prophet there were no provisions regarding compulsory zakat and what percentage had to be zakat. but can use analogy (qiyas).

Contemporary scholars such as Yusuf Qardhawi said, "The search and the profession can be taken for zakat if it has been a year and it has been senisab. If we adhere to the opinion of Abu Hanifah, Abu Yusuf and Muhammad that the nisab does not need to be achieved throughout the year, but it is sufficient to be fully achieved between the two ends of the year without missing the middle, we can conclude that with this interpretation it is possible to oblige zakat on the results of each search. the year, because the yield seldom stops throughout the year, mostly reaching both sides of the year. Based on this, we can determine the search results as a source of zakat, because of the presence of illat (cause), which according to the scholars of fiqh is valid, and nisab, which is the basis for compulsory zakat.

\section{h. Zakat on Shares and Bonds}

This modern era recognizes a form of wealth created by advances in industry and commerce in the world, which are called "stocks and bonds". Stocks and bonds are paper securities that apply in special trading transactions called "marketable paper exchanges" and impose a tax on their income that is always flowing, which is called "opinion tax on carried value", some even want the tax to be levied on the stock itself on the basis that the tax is a tax on property.

The ratio of zakat on shares is analogous to zakat on gold and silver worth 85 grams of pure gold, the amount of zakat issued is $2,5 \%$ with up to one year. The nisab of zakat on bonds is associated with zakat on gold and silver, which is 85 grams of pure gold, the zakat content is $2,5 \%$ with a period of up to one year.

\section{Discussion}

\subsection{Zakat Management According to Law no. 38 of 1999}

In Law Number 38 of 1999 concerning zakat management, there are several important points of view that are important to note as follows:

a. Zakat management is the activity of planning, implementing and supervising the collection and distribution and utilization of zakat. 
b. Zakat is a property that must be set aside by a Muslim or an entity that is owned by a Muslim after fulfilling the mandatory zakat provisions in accordance with the provisions of Islamic law to be given to those entitled to receive it.

c. Every Indonesian citizen who is Muslim and capable or an entity owned by a Muslim is obliged to pay zakat.

d. Zakat here consists of zakat fithrah and zakat on assets subject to zakat, which are: (a) Gold, silver and money, (b) Trade and companies, (c) Agricultural products, plantation products and fishery products, (d) mining products, livestock products , (e) Income and services, (f) Rikaz.

e. Zakat management is carried out by the Amil Zakat Agency which is formed by the government which consists of the community and government elements at the regional level. Namely BAZNAS (National Zakat Agency), Provincial Amil Zakat Board, Regency / City Amil Zakat Board and District Amil Zakat Board.

f. The government is obliged to provide protection, guidance and services to muzakki, mustahik and amil zakat.

g. The Amil Zakat Institution (LAZ), which is formed and managed by the community which is grouped in various Islamic mass organizations, foundations and other institutions, is confirmed, fostered and protected by the government.

h. The Amil Zakat Agency as referred to in article 6 and the Amil Zakat Institution as referred to in article 7 have the main task of collecting, distributing and utilizing zakat in accordance with religious provisions.

i. The results of zakat collection are utilized for mustahiq in accordance with religious provisions as well as the utilization of the results of zakat collection based on the priority scale of mustahiq needs and can be used for productive business.

j. The management of zakat includes the management of infaq, alms, grants, wills, inheritance and kafarat.

An officer who commits an offense due to his negligence in not recording or recording incorrectly the assets of zakat, infaq, alms, grants, wills, inheritance and kafarat as referred to in article 8, article 12 and article 13 of this law shall be punished with a maximum imprisonment sentence the duration of three months and or a fine of up to Rp. 30,000,000, (thirty million rupiah).

\subsection{Management of Zakat in accordance with Law No. 23 of 2011}

In terms of zakat management according to law number 23 of 2011 there are no fundamental changes. Therefore, law number 23 of 2011 can be said to be a complementary law from the previous law, namely law number 38 of 1999 . So that the substance and content of Law No. 23 of 2011 are not much different from the Law. -Act number 38 of 1999.

In Law number 23 of 2011, it explains that zakat management is an activity of planning, implementing, and coordinating the collection, distribution and utilization of zakat. Zakat is an asset that must be issued by a Muslim, or a business entity owned by a Muslim to be given to those entitled to receive it in accordance with Islamic law. Which includes zakat mal and zakat fithrah. For this the authors take a summary of the contents of law number 23 of 2011 as follows:

1. Zakat management is based on:

Islamic Sharia, Trust, Benefit, Justice, Legal certainty, Integrated and Accountability.

2. Zakat management objectives:

Improve the effectiveness and efficiency of services in managing zakat

Increase the benefits of zakat to create social welfare and poverty alleviation 
3. Zakat mal is zakat that is owned by muzakki individually or as a business entity. Zakat mal includes:

Gold, silver and other precious metals, Money and other securities, Commerce/ commerce, Agriculture, plantation and forestry, Animal husbandry and fisheries, Mining, Industry, Income and services, Rikaz.

4. The conditions for assets subject to zakat:

Owned in full, Halal, Developing, Reach one nisab, More than usual, Debt free Haul/ have reached one year.

5. Zakat Management Institution

In carrying out their duties and functions, BAZNAS, Provincial BAZNAS, and Regency/City BAZNAS can form Zakat Collection Units (UPZ) in government agencies, state-owned enterprises, region-owned enterprises, private companies, and representatives of the Republic of Indonesia abroad and can establish a UPZ at the level of sub-district, sub-district or other names, and other places. Further provisions regarding the organization and work procedures of the Provincial BAZNAS, Regency/City BAZNAS are regulated in a Government Regulation.

\section{Regency/City National Amil Zakat Board}

In the implementation of zakat management at the Regency/City level, a District/ City BAZNAS is formed. The district/municipal BAZNAS organization consists of the Advisory Council, the Supervisory Commission and the Implementing Body. The Implementing Body consists of a Chairman, a Secretary, a Head of the Collection section, a Head of Distribution section, a Head of Utilization and a Head of Development. The Advisory Council consists of a Chairman, a secretary and 2 (two) members. The district/ municipal BAZNAS management consists of elements from scholars, professional staff, Muslim community leaders and government representatives. BAZNAS Regency / City is assisted by secretariat in carrying out its duties.

District/City BAZNAS Implementing Bodies are in charge; First, Carrying out administrative and technical tasks of collecting, distributing and utilizing zakat. Second collect and process the data required for the preparation of plans for collection, distribution and utilization of zakat. Third Organizing guidance in the field of collection, distribution and utilization of zakat. Fourth, Carrying out research and development, communication, information and education tasks in the field of collection, distribution and utilization of zakat.

\subsection{Management of Zakat Mall at LAZISMU Medan City}

The management of Zakat Mall contained in Lazis Muhammadiyah Medan City is in substance in accordance with the mandate of Law no. 23 of 2011 concerning Zakat Management. As for what is meant by the management of zakat as follows the activities of planning, organizing, implementing and monitoring the collection and distribution and utilization of zakat.

In this case, Lazis Muhammadiyah Medan City is a zakat management institution and it can be seen from the data released in the period 2019-March 2020, lists of the implementation of zakat collection are listed as follows. 
Table 5. ZIS data from LazisMu 2019-2020

\begin{tabular}{|c|r|r|r|r|r|}
\hline Month & \multicolumn{1}{|c|}{ Zakat } & \multicolumn{1}{c|}{ Infak } & \multicolumn{1}{c|}{ Mukayyat } & Zakat Fitrah & \multicolumn{1}{c|}{ Total } \\
\hline January & Rp.5.466.875 & Rp.38.909.889 & Rp.2.715.011 & & Rp.47.091.775 \\
\hline February & Rp.2.790.000 & Rp.30.733.900 & & & Rp.33.523.900 \\
\hline March & Rp.2.250.000 & Rp.36.528.400 & Rp.3.860.000 & & Rp.42.638.400 \\
\hline April & Rp.1.250.000 & Rp.63.371.600 & Rp.1.790.000 & & Rp.66.411.600 \\
\hline May & Rp.16.400.000 & Rp.89.417.300 & Rp.5.030.000 & & Rp.110.847.300 \\
\hline June & Rp.38.570.000 & Rp.175.305.400 & Rp.150.000 & Rp.488.000 & Rp.214.513.400 \\
\hline July & Rp.1.463.625 & Rp.55.929.900 & Rp.5.899.000 & & Rp.63.292.525 \\
\hline August & Rp.1.825.000 & Rp.46.544.600 & Rp.1.000.000 & & Rp.49.369.600 \\
\hline September & Rp.13.375.000 & Rp.55.197.400 & Rp.3.489.500 & & Rp.72.061.900 \\
\hline October & Rp.700.000 & Rp.49.475.900 & Rp.36.542.700 & & Rp.86.718.600 \\
\hline November & Rp.1.685.000 & Rp.40.396.000 & Rp.300.000 & & Rp.42.381.000 \\
\hline December & Rp.1.145.000 & Rp.47.329.100 & Rp.7.835.300 & & Rp.56.309.400 \\
\hline Total & Rp.86.920.500 & Rp.729.139.389 & Rp.68.611.511 & Rp.488.000 & Rp.884.671.400 \\
\hline
\end{tabular}

Data: LAZIS Muhammadiyah Medan City Office, Tuesday, March 11, 2020.

For this reason, that the management of zakat does not only revolve around the principle of collection and distribution, but what is more important is the realization of planning, organizing, implementing and controlling the collection and distribution and utilization of zakat. LAZIS Muhammadiyah Medan City.

According to Islamic teachings, zakat should be collected by the state or institution mandated by the state and on behalf of the government acting as the representative of the poor. To get his rights that are in the wealth of the rich. Management under the authority of an agency established by the state will be much more effective in carrying out its functions and impacts in building the welfare of the people who are the goal of zakat itself, compared to zakat collected and distributed by institutions that run independently without any coordination with each other.

Whereas in the provisions of the Muhammadiyah Central Leadership Guidelines regarding Lazismu article 4 concerning the principle in paragraph (1) "Islamic Sharia, meaning that in carrying out its duties and functions, it must be guided in accordance with Islamic law, starting from the procedure for recruiting employees to the procedure for distributing ZISKA funds". In this provision, that Lazis Muhammadiyah in managing zakat certainly rests on the principles of Islamic law. It was even reaffirmed in the mandate issued by the Minister of Religion of the Republic of Indonesia with the Decree of the Minister of Religion No. 73 of 2016 that LAZISMU is a zakat institution.

\section{Conclusion}

Management of zakat based on Law Number 23 of 2011 is zakat management states that zakat management aims to increase the effectiveness and efficiency of services in managing zakat; and increase the benefits of zakat to create social welfare and poverty alleviation. Efforts to realize the function and role of zakat in the welfare of society, the zakat management law issued by the government is in principle to facilitate, motivate and confirm the management of zakat issued by the Amil Zakat Agency or the Amil Zakat Institute.

The problems and strategies carried out by the Lazis Muhammadiyah management in Medan are divided into two, namely internal and external. And what is being done is an effort to raise awareness together to channel zakat al-mal to Lazis Muhammadiyah so that 
it is managed properly and transparently and evenly so that it directly touches the community so that the objectives of the zakat law are realized.

\section{References}

al-Bukhari, Muhammad Ibn Ismail. Matan Masykul bi Hasyiyatis Sanadi, Mesir: Dar ihya il-Kutubil, Isa al-Babi al-Halabi, tt.

al-Umrani, Imam Abi Husain Yahya Ibnu Abi al-Khair. Al-Bayan fi Syarhi alMuhazzab, Beirut: Daar al-Fikr.

Ari Murti dan Rahmani Timorita Yulianti, Pengelolaan Lembaga Amil Zakat Infaq dan Shadaqah Muhammadiyah Banyumas Dalam Pemberdayaan Ekonomi Umat Perspektif Ekonomi Islam, tp.th.

Ash-shiddiqie, M. Hasbi. Pedoman zakat, Semarang; PT. Pustaka Rizki Putra, 2009.

asy-syarbini, Syamsuddin Muhammad ibnu Muhammad. Mughni al-Muhtaj ila Ma'rifati Ma'ani Al-Fazi Al-Minhaj, Kairo: Daar al-Hadis, 2006.

At-Turmudzi, Abu Isa. Sunan At-Turmudzi, (Beirut: Daar al-Garb al-Islami, 1996.

Dao, M. Jama. Membangun Ekonomi Umat Melalui Zakat Harta, Jakarta: Nusantara Madani, 2001.

Departemen Agama RI, Al Quran dan Terjemahannya, Semarang: PT. Karya Toha Putra 1995.

Hafizi, Modernisasi Pengelolaan Zakat di Lazismu, Surakarta: Program Studi Hukum Ekonomi Syariah Fakultas Agama Islam Universitas Muhammadiyah Surakarta 2017.

Hamzah, Disertasi Pendayagunaan Zakat pada Badan Amil Zakat Nasional Dalam Meningkatkan Kesejahteraan Umat, (Jakarta: Universitas Islam Syarif Hidayatullah 2009.

Hasan, M. Ali. Zakat dan Infaq, Jakarta; Kencana Perdana Media Group, 2008.

Iqbal, Muhammad. Fiqih Siyasah, kontekstualisasi Doktrin Politik Islam, Jakarta: Gaya Media Pratama, 2001.

Jmoelong, Lexi. Metode Penelitian Kualitatif, Bandung: Remaja Rosda Karya, 1998.

Khoiri, Nispul. Hukum Perzakatan di Indonesia, Medan, Cita Pustaka, 2012.

Koencoroningrat, Dalam Metode-Metode Penelitian Masyarakat, Jakarta: Gramedia, 1977.

Mas'udi, Masdar Farid. Pajak Itu Zakat Uang Allah Untuk Kemaslahatan Rakyat, Jakarta : Mizan Pustaka, 2010.

Mufraini, M. Arief. Akuntansi dan Manajemen Zakat, Jakarta, Kencana, 2006.

Munzir Ibnu. Lisan al-Arab, Beirut: Daar Saadir, 1996.

Nasution, Lahmuddin . Pembaharuan Hukum Islam Dalam Mazhab Syafi'i, Bandung : Remaja Rosdakarya, 2001.

Qadir, Abdur Rahman. Zakat (dalam dimensi Mahdlhah dan Sosial), Jakarta: PT. Raja Grafindo Persada, 2001.

Qardhawi, Yusuf. Hukum Zakat, Terj. Salman Harun, dkk, Jakarta; Litera Antar Nusa,2007.

Fiqh az-Zakah, Beirut: Muassasah Risalah, 1991.

Rasjid, Sulaiman. Fiqh Islam, Bandung; Sinar Baru, 1988.

Safitri, Junaidi. Implementasi Konsep Zakat dalam Al- Qur'an Sebagai Upaya Mengentaskan Kemiskinan Di Indonesia, Jurnal: Studi IslamVolume 2, No. 1, Juni 2017.

Suma, Muhammad Amin. Pengelolaan Zakat Dalam Perspektif Sejarah, Dalam Buku Problematika Zakat Kontemporer Artikulasi Proses Sosial Politik Bangsa, Jakarta: Forum Zakat, 2003. 
Tim Penyusun Kamus, Pusat Pembinaan dan Pengembangan Bahasa, Kamus Besar Bahasa Indonesia (KBBI) Edisi kedua, Jakarta: Balai Pustaka, 1995.

Zuhaili, Wahbah. Fiqh al-Islam wa Adillatuh, Jakarta: Gema Insani, 2011.

Law

Keputusan Menteri Agama RI No. 273 tahun 2003 tentang Pelaksanaan Undang-undang No. 38 tahun 1999 tentang Pengelolaan Zakat.

Lazismu Medan Proposal Program Pendayagunaan \& Pendistribusia tahun 2020.

Pedoman Pimpinan Pusat Muhammadiyah Tentang Lazismu.

Pembukaan Undang-Undang Dasar Negara Republik Indonesia alinea 4.

Pengarahan Presiden Susilo Bambang Yudoyono, dalam rapat Rakortas di

Gedung Agung Istana Negara Yogyakarta, 14 Desember 2006, tentang

Pembukaan Lapangan Kerja dan Pengurangan Kemiskinan, "Pemerintah Buka

Lapangan Kerja." Republika, 15 desember 2006.

Rancangan Peraturan Menteri Agama RI tahun 2011 tentang syarat dan Tata Cara

Perhitungan Zakat serta Pendayagunaan Zakat untuk Usaha Produktif.

Rancangan Peraturan Pemerintah RI tahun 2011 tentang pelaksanaan Undang-undang No. 23 tahun 2011 tentang Pengelolaan Zakat.

Undang-undang No. 23 tahun 2011 Tentang Pengelolaan Zakat

Undang-Undang Nomor 38 tahun 1999.

\section{Interview}

Mr. Putra al-Khair, Privacy Interview, at Lazismu office Medan city, Tuesday, December $29^{\text {th }} 2020(10.00 \mathrm{Wib})$. 